Pobrane z czasopisma Annales I - Philosophy and Sociology http://philosophia.annales.umcs.pl Data: 26/04/2023 14:08:03

DOI: $10.17951 / \mathrm{i} .2018 .43 .1 .215-231$

\begin{tabular}{lcc}
\hline \multicolumn{2}{c}{ A N N A LES } \\
UNIVERSITATIS M A R I A E C URIE-SK L ODOWSK A \\
LOL. XLIII, 1 & SECTIO I & 2018 \\
\hline
\end{tabular}

MARCEL BLOCH

ORCID ID: https://orcid.org/0000-0002-9893-0702

Uniwersytet Wrocławski

\title{
Zmiany klimatu jako czynnik warunkujący transformację przyszłych stosunków międzynarodowych
}

Climate Change as a Transformation Determinant of Future International Relations

\section{WPROWADZENIE}

Współczesne zmiany klimatu są jednym z największych zagrożeń nie tylko dla środowiska naturalnego, ale także dla życia i rozwoju ludzi, zarówno jednostek, jak i całych zbiorowości. Konsekwencje tego procesu w różnym stopniu, w sposób pośredni lub bezpośredni, oddziałują na życie większości ludzi na Ziemi. Sytuacja ta nie pozostaje bez wpływu również na relacje społeczne w obrębie państw i pomiędzy nimi. Mając na uwadze powyższe, zamierzeniem autora jest opisanie zależności między działalnością człowieka i zmianami klimatu, które w konsekwencji zaważą na życiu społecznym, prowadząc też do zmian w środowisku międzynarodowym, co prawdopodobnie będzie istotnym czynnikiem rzutującym na transformację stosunków międzynarodowych w przyszłości.

Podstawę dla koncepcji zmiany w stosunkach międzynarodowych stanowić będzie założenie M. Pietrasia o hybrydowości współczesnego, późnowestfalskiego ładu międzynarodowego ${ }^{1}$. Według tego podejścia obecne stosunki międzynarodowe są kształtowane przez szereg nowych jakościowo zjawisk, które nie są przypisane do określonego miejsca, będąc jednocześnie pozbawionymi ograniczeń wynikających z dystansów i granic. Są to czynniki, które ze względu na opisane powyżej cechy nie mogą zostać ograniczone lub wyeliminowane przez działania

1 M. Pietraś, Hybrydowość późnowestfalskiego ładu międzynarodowego, [w:] M. Pietraś, K. Marzęda-Młynarska (red.), Późnowestfalski ład międzynarodowy, Lublin 2008, s. 57-74. 
Pobrane z czasopisma Annales I - Philosophy and Sociology http://philosophia.annales.umcs.pl Data: 26/04/2023 14:08:03

216 Marcel Błoch

pojedynczego państwa. Jednym z nich, jak zauważył M. Pietraś, są transgraniczne problemy ekologiczne, w tym zmiany klimatu, które w niniejszym opracowaniu stanowią podstawową zmienną oddziałującą na strukturę stosunków międzynarodowych, a w dalszej perspektywie - także ładu międzynarodowego.

Realizacja podstawowego założenia pracy, jakim jest wyjaśnienie znaczenia współczesnych zmian klimatu dla kształtowania nowego, powestfalskiego porządku międzynarodowego, zostanie wykonana w oparciu o dane zastane, zawierające informacje o już zauważonych skutkach zmian klimatu oraz tych, które są przewidywane na przyszłość.

Warto zaznaczyć, że M. Pietraś jest też autorem opracowania zatytułowanego Międzynarodowy reżim zmian klimatu ${ }^{2}$, w którym znajdują się cenne informacje na temat kształtowania globalnej polityki klimatycznej i czynników spowalniających jej rozwój również współcześnie. W literaturze polskojęzycznej można znaleźć ponadto inne, bardziej szczegółowe, opracowania dotyczące skutków zmian klimatu, w tym Zmiany klimatu a bezpieczeństwo narodowe Polski Z. Karaczuna³. Ze względu na ograniczoną objętość artykułu i założenia przyjęte dla realizacji niniejszego opracowania, prace te zostały jednak pominięte.

W celu zrealizowania wymienionych powyżej założeń opisano związek pomiędzy działalnością człowieka a wzrostem stężenia gazów cieplarnianych w atmosferze, prowadzący do podniesienia średniej globalnej temperatury i wielu innych zmian w środowisku naturalnym. Wykazano także znaczenie tych przeobrażeń dla życia pojedynczych ludzi i całych społeczności, ze szczególnym zwróceniem uwagi na wybrane, najbardziej zagrożone na skutek tych transformacji, regiony. W dalszej kolejności wskazano podstawy współczesnych stosunków międzynarodowych. Przedstawienie najistotniejszych składowych ładu międzynarodowego umożliwiło przeprowadzenie jego krytycznej analizy w odniesieniu do nasilającego się problemu zmian klimatu. To działanie z kolei stało się podstawą do określenia przyszłych możliwych transformacji stosunków międzynarodowych, w zależności od przyjętego kierunku działań lub ich zaniechania.

\section{NAUKOWE PODSTAWY PROCESU ZMIAN KLIMATU}

N. Stern, ekonomista zajmujący się badaniem kosztów wynikających ze zmian klimatu, wyróżnił pięć najważniejszych powiązań w procesie zmian klimatu. Są to:

- działalność gospodarcza i emisje gazów cieplarnianych,

- emisje gazów cieplarnianych i koncentracja tych gazów w atmosferze,

2 Idem, Międzynarodowy reżim zmian klimatu, Toruń 2011.

3 Z. Karaczun, Zmiany klimatu a bezpieczeństwo narodowe Polski, Warszawa 2011. 
Pobrane z czasopisma Annales I - Philosophy and Sociology http://philosophia.annales.umcs.pl Data: 26/04/2023 14:08:03

Zmiany klimatu jako czynnik warunkujący transformację przyszłych stosunków...

- koncentracja gazów cieplarnianych w atmosferze i zmiany temperatury,

- zmiany temperatury i zmiany klimatu,

- zmiany klimatu i skutki społeczne $e^{4}$

Chociaż ostatnie powiązanie jest najistotniejsze dla badaczy z dziedziny nauk społecznych, z uwagi na złożoność opisywanego zjawiska nie można pominąć żadnego z tych elementów.

Od drugiej połowy XIX w. średnia temperatura na Ziemi wzrosła o około $0,8^{\circ} \mathrm{C}^{5}$. Przyczyną tak znacznej zmiany jest nadmierna emisja do atmosfery gazów cieplarnianych, pochodzących głównie ze spalania paliw kopalnych oraz, w mniejszym stopniu, z procesów rolniczych i zmian w użytkowaniu gruntów ${ }^{6}$. Przekraczając wielkość emisji, która w warunkach braku nadmiernej ingerencji człowieka w skład atmosfery była absorbowana przez naturalne procesy Ziemi ludzkość doprowadziła do znacznego zwiększenia ilości gazów cieplarnianych w atmosferze. Przez 400 tys. lat przed rewolucją przemysłową stężenie dwutlenku węgla (mającego obecnie największy wpływ na wzrost temperatury Ziemi ${ }^{7}$ ) wynosiło między 180 a 300 cząsteczek na milion cząsteczek powietrza (ppm) ${ }^{8}$. We wrześniu 2017 r., w czasie rocznego minimum, ilość dwutlenku węgla zarejestrowana w stacji badawczej w Mauna Loa na Hawajach wyniosła ponad 403 ppm. Było to o 2 cząsteczki więcej niż rok wcześniej ${ }^{9}$.

Klimatolodzy opracowali wiele prognoz dotyczących skutków nadmiernego wzrostu temperatury, uznając jego bezpieczną granicę na poziomie maksymalnie $2^{\circ} \mathrm{C} \mathrm{w}$ stosunku do epoki przedprzemysłowej ${ }^{10}$. Mając na uwadze, iż bariera ta najprawdopodobniej zostanie przekroczona na koniec XXI w., przy stężeniu gazów cieplarnianych $\mathrm{w}$ atmosferze $\mathrm{w}$ ekwiwalencie dwutlenku węgla na poziomie około $500 \mathrm{ppm}^{11}$, a także zważając na szybko postępujące zmiany w tym zakresie, na stabilizację koncentracji gazów cieplarnianych w tej ilości pozostało niewiele czasu. Gdyby światowe emisje $\mathrm{CO}_{2}$ i innych gazów, będących przyczyną nasilenia

4 N. Stern, Globalny ład. Zmiany klimatu a powstanie nowej epoki postępu i dostatku, Warszawa 2010, s. 115.

5 Zmiana klimatu 2013. Fizyczne podstawy naukowe. Podsumowanie dla Decydentów, Warszawa 2015, www.ipcc.ch/pdf/reports-nonUN-translations/polish/ar5-wg1-spm.pdf [dostęp: 30.04.2018], s. 3.

6 N. Stern, op. cit., s. 56; Rosna emisje gazów cieplarnianych z rolnictwa, http://dlaklimatu. pl/rosna-emisje-gazow-cieplarnianych-z-rolnictwam [dostęp: 30.05.2018].

7 Zmiana klimatu 2013..., s. 12.

$8 \quad$ M. Popkiewicz, Świat na rozdrożu, Katowice 2012, s. 370-371.

9 Trends in Atmospheric Carbon Dioxide, Earth System Research Laboratory, www.esrl. noaa.gov/gmd/ccgg/trends/graph.html [dostęp: 03.04.2018].

10 M. Popkiewicz, op. cit., s. 394.

11 R.K. Pachauri, L. Meyer (Hrsg.), Klimaänderung 2014. Synthesebericht, 2015, www.ipcc. ch/pdf/reports-nonUN-translations/deutch/IPCC-AR5_SYR_barrierefrei.pdf [dostęp: 03.04.2018]. 
Pobrane z czasopisma Annales I - Philosophy and Sociology http://philosophia.annales.umcs.pl Data: 26/04/2023 14:08:03

efektu cieplarnianego, pozostawały przez najbliższe lata na poziomie z drugiej dekady XXI w., aby ograniczyć ryzyko wzrostu temperatury do końca XXI w. o nie więcej niż $2^{\circ} \mathrm{C}$, około 2040 r. emisja gazów cieplarnianych z działalności ludzkiej musiałaby spaść do zera ${ }^{12}$. W przypadku wcześniejszego podjęcia działań, których celem byłoby zmniejszenie emisji tych gazów, wykorzystanie paliw kopalnych mogłoby odbywać się odpowiednio dłużej, gdyż istotna dla procesów zmian klimatu jest koncentracja gazów cieplarnianych w atmosferze, wyemitowanych na przestrzeni wielu lat. Ta sama zasada musiałaby dotyczyć wysokoemisyjnych gałęzi produkcji rolnej oraz leśnictwa. Aby ograniczyć wzrost średniej globalnej temperatury poniżej $2^{\circ} \mathrm{C}$ również w późniejszym czasie (po XXI w.), stężenie ekwiwalentu $\mathrm{CO}_{2}$ powinno spaść do poziomu około 400 ppm (350 ppm dwutlenku węgla) na koniec XXI w. ${ }^{13}$

\section{SPOŁECZNE KONSEKWENCJE ZMIAN KLIMATU}

Globalne ocieplenie nie jest jedynym skutkiem wzrostu emisji gazów cieplarnianych w atmosferze. Stanowi ono jednak czynnik warunkujący wiele innych przeobrażeń w systemie klimatycznym Ziemi. W raporcie Międzyrządowego Zespołu ds. Zmian Klimatu (IPCC) z 2014 r. zwrócono szczególną uwagę na kilka podstawowych zmian w środowisku naturalnym, wywołanych zarówno zwiększeniem koncentracji gazów cieplarnianych w atmosferze, jak i wzrostem temperatury. Zaliczono do nich przede wszystkim przekształcenia związane $\mathrm{z}$ atmosferycznym cyklem wodnym, środowiskiem oceanicznym, kriosferą i poziomem mórz ${ }^{14}$. Każda $\mathrm{z}$ tych zmian jest ponadto czynnikiem powodującym wiele innych transformacji w środowisku naturalnym, które w bezpośredni lub pośredni sposób wpływają na działalność ludzką.

Zmiany cyklu wodnego w atmosferze, związane ze wzrostem temperatury na Ziemi, w przypadku niepodjęcia działań mających na celu ograniczenie antropogenicznego wpływu na klimat, prawdopodobnie doprowadzą do większego zróżnicowania świata pod względem ilości opadów. W wysokich szerokościach geograficznych i regionach równikowych Oceanu Spokojnego przewidywany jest znaczny wzrost opadów atmosferycznych. Podobna sytuacja prawdopodobnie będzie dotyczyć niewielkiego obszaru w Afryce i południowej części Półwyspu Arabskiego. Poza tymi miejscami niewielki wzrost opadów obejmie swoim zasięgiem północną część Ameryki Północnej i Europy, Afrykę Środkową oraz

\footnotetext{
M. Popkiewicz, op. cit., s. 396.

Ibidem.

14 R.K. Pachauri, L. Meyer (Hrsg.), op. cit., s. 58-62.
} 
Pobrane z czasopisma Annales I - Philosophy and Sociology http://philosophia.annales.umcs.pl Data: 26/04/2023 14:08:03

Zmiany klimatu jako czynnik warunkujący transformację przyszłych stosunków...

większą część Azji, z wyłączeniem Bliskiego Wschodu, gdzie opady atmosferyczne na koniec obecnego stulecia będą wyraźnie niższe niż na przełomie XX i XXI w. Zmniejszenie opadów będzie dotyczyć także całego basenu Morza Śródziemnego, południowej i północno-zachodniej części Afryki oraz środkowych i południowych regionów Ameryki. Podobnych skutków doświadczy również prawie cała Australia ${ }^{15}$. Analizując przedstawione powyżej informacje, nietrudno zauważyć, że wzrost opadów atmosferycznych najprawdopodobniej będzie dotyczyć w zdecydowanej mierze obszarów wilgotnych lub słabo zaludnionych obszarów okołobiegunowych. Z kolei ich spadek będzie odczuwalny w regionach, w których już obecnie ludność zmaga się z niedoborami wody pitnej. Problemy te zostaną przypuszczalnie dodatkowo spotęgowane wzrastającą liczbą ludności zamieszkującą te tereny ${ }^{16}$.

Brak dostępu do czystej wody pitnej stanowi bezpośrednie zagrożenie dla zdrowia i życia ludzi. W 2015 r. dla 844 mln ludzi z całego świata dobro to w miejscu ich zamieszkania było nieosiągalne. Wśród nich $263 \mathrm{mln}$ osób przeznaczało ponad 30 minut na pieszą wędrówkę w celu jego zdobycia, a kolejne $159 \mathrm{mln}$ osób piło zanieczyszczoną wodę ze źródeł powierzchniowych ${ }^{17}$. Ograniczony dostęp do czystej wody i podstawowych urządzeń sanitarnych prowadzi do rozprzestrzeniania się wielu chorób, w tym chorób biegunkowych, cholery, czerwonki, żółtaczki typu A i duru brzusznego, w wyniku których każdego roku dochodzi do zgonów około 361 tys. dzieci poniżej 5. roku życia ${ }^{18}$. Jednym z wielu innych skutków przedłużających się okresów suszy będzie także zmniejszenie plonów rolnych, zarówno przez brak opadów atmosferycznych, jak i ograniczenie możliwości sztucznego nawadniania obszarów wykorzystywanych do produkcji żywności. To zaś może być przyczyną niedożywienia i problemów finansowych rolników, co następnie prawdopodobnie doprowadzi do niepokojów społecznych i migracji wewnątrzpaństwowych i zewnętrznych. Potwierdzeniem dla tego typu konsekwencji dla społeczeństwa, wynikających ze zmian klimatu, jest zapoczątkowana w $2011 \mathrm{r}$. wojna domowa w Syrii. Jak wskazali autorzy raportu pt. Climate change in the Fertile Crescent and implications of the recent Syrian drought, trwająca 3 lata

15 Ibidem, s. 63.

16 Population, total, https://data.worldbank.org/indicator/SP.POP.TOTL?name desc=false$\&$ view $=$ chart [dostęp: 03.04.2018].

17 Progress on Drinking Water, Sanitation and Hygiene, www.unicef.org/publications/files/ Progress_on_Drinking_Water_Sanitation_and_Hygiene_2017.pdf [dostęp: 03.04.2018], s. 3.

${ }_{18}$ 2,1 mld ludzi na świecie nie ma dostępu do wody pitnej w miejscu zamieszkania, a ponad $d$ wa razy więcej pozbawionych jest odpowiednich warunków sanitarnych, www.unicef.pl/Centrum-prasowe/Informacje-prasowe/2-1-mld-osob-na-swiecie-nie-ma-dostepu-do-wody-pitnej-w-miejscuzamieszkania-a-ponad-dwa-razy-wiecej-pozbawionych-jest-odpowiednich-warunkow-sanitarnych [dostęp: 30.05.2018]. 
Pobrane z czasopisma Annales I - Philosophy and Sociology http://philosophia.annales.umcs.pl Data: 26/04/2023 14:08:03

susza (2007-2010) doprowadziła do zwiększenia niedoboru wody w Syrii, co spowodowało znaczący spadek produktywności w rolnictwie, w tym wyraźny wzrost śmiertelności zwierząt. W wyniku tego problemu istotnie pogorszyła się sytuacja materialna wielu osób, przez co około 1,5 mln mieszkańców syryjskich wsi wyemigrowało na obrzeża miast ${ }^{19}$. Problemy spowodowane zmianami klimatu nie były jedyną przyczyną wybuchu wojny domowej w Syrii, ale wśród innych stały się jednym z istotniejszych czynników prowadzących do takiego rozwoju wydarzeń.

$\mathrm{Z}$ drugiej strony zagrożeniem dla społeczeństwa wynikającym ze zmiany cyrkulacji wodnej w atmosferze są nadmierne opady. Ilość pary wodnej, która może pomieścić się w atmosferze, wzrasta wraz z temperaturą. Równocześnie zwiększa to możliwość wystąpienia ekstremalnych ilości opadów, czego konsekwencją mogą być powodzie ${ }^{20}$. Za przykład takich zmian, skutkujących zwiększeniem zagrożenia dla ludzi, może posłużyć monsun. Według prognoz przedłuży się sezon letni tych wiatrów, które przynoszą znaczne opady nad lądem. Dodatkowo jego opady będą bardziej intensywne niż współcześnie ${ }^{21}$. W 2016 r. wzmożone opady doprowadziły w Indiach do zalania obszaru zamieszkanego przez 1,5 mln ludzi, a piasek naniesiony wraz z wodą uniemożliwił wykorzystanie wielu pól uprawnych ${ }^{22}$. Do połowy lipca 2017 r. tylko w jednej prowincji Indii - Asam, swoje domy musiało opuścić 2 mln osób. W sąsiednim Bangladeszu było to kolejne 650 tys. mieszkańców ${ }^{23}$. Na koniec sierpnia tego samego roku liczba osób, która została bezpośrednio narażona na negatywne skutki powodzi, wynosiła $17 \mathrm{mln}$, w tym ponad 1200 osób to ofiary śmiertelne ${ }^{24}$. Nasilenie intensywności opadów w okresie wilgotnym będzie prowadziło do znacznie większych strat zarówno materialnych, jak i związanych z życiem ludzkim.

Negatywne konsekwencje zmian klimatu dotyczą również oceanów, które są odpowiedzialne za pochłanianie około $25 \%$ emitowanego przez ludzi dwutlenku

19 C.P. Kelley, S. Mohtadib, M.A. Canec, R. Seagerc, Y. Kushnirc, Climate change in the Fertile Crescent and implications of the recent Syrian drought, www.pnas.org/content/112/11/3241. full.pdf [dostęp: 03.04.2018], s. 3241-3246.

20 J. Cowie, Zmiany klimatyczne. Przyczyny, przebieg i skutki dla człowieka, Warszawa 2009, s. 315.

${ }_{21}^{21}$ R.K. Pachauri, L. Meyer (Hrsg.), op. cit., s. 62-64.

22 P. Skawiński, Monsun przynosi teraz tylko nieszczęście, http://wiadomosci.dziennik. pl/swiat/artykuly/533833, indie-monsun-powodz-nieszczescie-reportaz-zdjecia.html [dostęp: 03.04.2018].

23 Powódź, monsun, osuwiska. Sity natury pustosza Azję, https://tvnmeteo.tvn24.pl/informacje-pogoda/swiat,27/powodz-monsun-osuwiska-sily-natury-pustosza-azje,236465,1,0.html [dostęp: 03.04.2018].

24 Tragiczne skutki monsunu. 1200 ofiar śmiertelnych, miliony osób bez dachu nad głowa, https:/tvnmeteo.tvn24.pl/informacje-pogoda/swiat,27/tragiczne-skutki-monsunu-1200-ofiarsmiertelnych-miliony-osob-bez-dachu-nad-glowa,239439,1,0.html [dostęp: 03.04.2018]. 
Pobrane z czasopisma Annales I - Philosophy and Sociology http://philosophia.annales.umcs.pl Data: 26/04/2023 14:08:03

Zmiany klimatu jako czynnik warunkujący transformację przyszłych stosunków...

węgla ${ }^{25}$. Od początku epoki przemysłowej doprowadziło to do obniżenia o $0,1 \mathrm{pH}$ wód oceanicznych ${ }^{26}$. Wzrost temperatury wody w oceanach, w połączeniu ze zwiększeniem ich zakwaszenia, stanowi zagrożenie dla rozwoju wielu organizmów żywych. Wyginięcie tylko kilku gatunków może doprowadzić do przerwania wielu łańcuchów pokarmowych, zagrażając przetrwaniu innych gatunków, co w konsekwencji będzie miało negatywne skutki nie tylko dla bioróżnorodności, ale i dla ludności, której głównym źródłem pożywienia i utrzymania są organizmy morskie $^{27}$. Ponadto wzrost temperatury oceanów może doprowadzić do zmian cyrkulacji wody i powietrza. Bardzo prawdopodobne jest, że w XXI w. znacznie osłabnie atlantycka cyrkulacja termohalinowa, która jest odpowiedzialna za łagodny klimat północno-zachodniej Europy ${ }^{28}$.

Wzrost globalnej temperatury już obecnie prowadzi do zmian w kriosferze Ziemi. Jednym z najbardziej wrażliwych obszarów w tym zakresie jest Arktyka. Nawet jeśli ludzkość podejmie zdecydowane działania w celu zmniejszenia emisji gazów cieplarnianych do atmosfery, nie uda się całkowicie zatrzymać już zachodzących tam procesów. Do końca XXI w., w stosunku do stanu z początku tego stulecia, można jednak ograniczyć ubytek powierzchni pokrytej lodem w tej części świata do około $50 \%$ we wrześniu (miesiącu, w którym występuje minimum zlodowacenia Arktyki). W przypadku dalszego wzrostu emisji gazów cieplarnianych obszar ten już na początku drugiej połowy obecnego wieku, w czasie rocznego minimum, może być wolny od lodu ${ }^{29}$. Zwiększanie niezamarzniętej powierzchni na tej przestrzeni ma istotne znaczenie dla nasilenia rywalizacji pomiędzy państwami graniczącymi z Arktyką, których jednym z celów jest osiągnięcie korzyści gospodarczych $\mathrm{z}$ dostępu do surowców naturalnych znajdujących się na tym obszarze ${ }^{30}$. Należy jednocześnie zaznaczyć, że wraz ze zmniejszeniem pokrywy lodowej Arktyki proces wzrostu temperatury na Ziemi ulega nasileniu poprzez oddziaływanie dodatniego sprzężenia zwrotnego, związanego z większą absorpcją światła słonecznego, wchłanianego przez śnieg

2520 faktów o zakwaszeniu oceanów, http://naukaoklimacie.pl/aktualnosci/20-faktow-o-zakwaszaniu-oceanow-42 [dostęp: 30.05.2018].

26 M. Kozielecki, Co to jest zakwaszenie oceanów?, www.zielonazmiana.pl/edukacja/ekologia/zakwaszenie-oceanow [dostęp: 03.04.2018].

27 Ibidem.

28 R.K. Pachauri, L. Meyer (Hrsg.), op. cit., s. 64; M. Śmigrowska, M. Popkiewicz, Golfsztrom najstabszy od ponad 1000 lat, http://ziemianarozdrozu.pl/artykul/3009/golfsztrom-najslabszy-od-ponad-1000-lat [dostęp: 03.04.2018].

29 R.K. Pachauri, L. Meyer (Hrsg.), op. cit., s. 62.

30 P. Ciszak, Arktyka nowym El Dorado Putina. Rosja szykuje się do wojny o surowce ukryte pod lodem, www.money.pl/gospodarka/wiadomosci/artykul/arktyka-ropa-gaz-rosja-usa,23,0, 2320151.html [dostęp: 03.04.2018]. 
i lód jedynie w $15 \%$, natomiast przez wodę - nawet w około $90 \%^{31}$. Roztapianie lądolodów, obok rozszerzalności termicznej wody, jest z kolei najważniejszym czynnikiem wpływającym na wzrost poziomu mórz i oceanów ${ }^{32}$. Oddziaływanie tej zmiany na życie ludzi zostanie opisane w dalszej części artykułu. Ocieplenie klimatu powoduje także topnienie lodowców górskich. Dla przykładu temperatury w wysokich Himalajach wzrosły od połowy lat 70 . XX w. o około $1^{\circ} \mathrm{C}$. Prowadzi to do szybszego topnienia lodowców tego pasma górskiego, czego skutkiem, na obszarach zasilanych przez jego wody, są wzmożone powodzie i zwiększenie nasilenia osunięć ziemi. W dłuższej perspektywie czasowej znaczny ubytek lodowców zasilających największe rzeki Azji będzie jednak prowadził do niedoborów czystej wody. Będące tego skutkiem wyraźne zmniejszenie przepływu wody w rzece Ganges, w okresie pomiędzy lipcem a wrześniem, może doprowadzić do jej niedostatku dla $500 \mathrm{mln}$ ludzi i ponad 1/3 nawadnianych terenów Indii ${ }^{33}$.

Wzrost poziomu mórz, o którym już wspomniano, jest jednym z największych zagrożeń dla ludzi, wynikającym ze zmian klimatu. W zależności od ilości emisji gazów cieplarnianych i wzrostu temperatury na Ziemi w najbliższych latach poziom mórz i oceanów podwyższy się prawdopodobnie od około $45 \mathrm{~cm}$ do około $75 \mathrm{~cm}$ do końca XXI w. ${ }^{34}$ Należy mieć na uwadze, że dalsze tempo podnoszenia się poziomu wody (po XXI w.) zależne jest w zdecydowanej mierze od wzrostu stężenia gazów cieplarnianych w atmosferze w ciągu najbliższych dziesięcioleci. W dłuższej perspektywie czasowej, w przypadku stopienia się całej pokrywy lodowej Grenlandii, poziom mórz podniósłby się o 6,5 m. Gdyby roztopieniu uległ także cały lądolód Antarktydy, łączny wzrost poziomu mórz i oceanów wyniósłby $80 \mathrm{~m}$. Ze względu na długotrwałość takiego procesu jego skutki na tak dużą skalę byłyby widoczne jednak dopiero w kolejnych wiekach ${ }^{35}$. Prognozowany w V Raporcie IPCC wzrost poziomu wody do końca obecnego wieku, chociaż może wydawać się nieznaczny, stanowi duże zagrożenie dla wielu ludzi na świecie. W samym Bangladeszu, który w 2016 r. zamieszkiwało blisko 163 mln ludzi ${ }^{36}$, w połowie XXI w., na skutek podniesienia się poziomu oceanów, około $10-30 \mathrm{mln}$ mieszkańców z południowych wybrzeży kraju będzie zmuszonych do zmiany miejsca zamieszkania, prowadząc do jeszcze większego zagęszczenia ludności

\footnotetext{
31 M. Popkiewicz, op. cit., s. 352.

2 Z. Kundzewicz, Cieplejszy świat. Rzecz o zmianach klimatu, Warszawa 2013, s. 82.

3 N. Stern, op. cit., s. 41-42.

34 R.K. Pachauri, L. Meyer (red.), op. cit., s. 62.

35 J. Cowie, op. cit., s. 246.

$36 \mathrm{https}$ ://data.worldbank.org/indicator/SP.POP.TOTL?locations=BD\&name_desc $=$ false$\&$ view=chart [dostęp: 03.04.2018].
} 
Pobrane z czasopisma Annales I - Philosophy and Sociology http://philosophia.annales.umcs.pl Data: 26/04/2023 14:08:03

Zmiany klimatu jako czynnik warunkujący transformację przyszłych stosunków...

223

w innych częściach obecnie już silnie zaludnionego państwa ${ }^{37}$. Gdyby poziom morza podwyższył się o $1 \mathrm{~m}$, bezpośrednie zagrożenie tym zjawiskiem objęłoby około 150 mln ludzi w Azji ${ }^{38}$. Problem dotyczący wzrostu poziomu mórz, obok strat materialnych związanych m.in. z utratą miejsca zamieszkania, najprawdopodobniej będzie prowadził do szeregu innych negatywnych skutków społecznych: od nadmiernego zaludnienia obszarów, na które będą migrować osoby z zalanych terenów, przez ubóstwo oraz ograniczenie zasobów żywnościowych i czystej wody pitnej, po wzrost niezadowolenia społecznego i konflikty.

\section{WSPÓŁCZESNY ŁAD MIĘDZYNARODOWY I PERSPEKTYWA JEGO ZMIANY}

Nasilenie skutków zmian klimatycznych jest zależne w zdecydowanej mierze od podjęcia lub zaniechania czynności mających na celu ograniczenie dalszego wzrostu średniej temperatury na Ziemi przez zmniejszenie emisji gazów cieplarnianych z działalności ludzkiej. Zabiegi te będą prowadziły do zmian w funkcjonowaniu obecnego ładu społecznego zarówno w obrębie państw i regionów, jak i całego globu. Aby wskazać możliwe przeobrażenia tego porządku, należy zwrócić uwagę na obecne podstawy ładu międzynarodowego i stosunków pomiędzy państwami.

Od czasu zakończenia w 1648 r. trwającej 30 lat wojny religijnej w Europie stosunki międzynarodowe opierają się na zasadzie suwerenności państw, oznaczającej wyłączność sterowania życiem społecznym na określonym terytorium oraz niezależne od innych podmiotów stosunków międzynarodowych wypełnianie zadań dotyczących m.in. bezpieczeństwa i sprawiedliwości ${ }^{39}$. Suwerenność pozwoliła na kształtowanie polityki wewnętrznej i zagranicznej państwa w wybrany przez jego władze sposób, a zważanie na innych aktorów stosunków międzynarodowych stało się istotne jedynie w przypadku realizacji interesów własnego państwa bądź zagrożenia ze strony innych podmiotów dla jego pomyślnego rozwoju lub istnienia. Stosunki pomiędzy państwami były z kolei regulowane przede wszystkim przez prawo międzynarodowe ${ }^{40}$. Za sprawą procesów globalizacji i czynników je warunkujących stosunki międzynarodowe w ostatnich dekadach zostały jednak poddane pewnym modyfikacjom, czyniącym współczesny ład międzynarodowy hybrydowym pomiędzy ładem westfalskim a jego nową formą. Ten stan przejściowy

37 Bangladesz. Przed nami sztorm, www.national-geographic.pl/national-geographic/ludzie/ bangladesz-przed-nami-sztorm [dostęp: 03.04.2018].

38 N. Stern, op. cit., s. 40.

39 M. Pietraś, Hybrydowośćc..., s. 57.

40 Ibidem, s. 59. 
Pobrane z czasopisma Annales I - Philosophy and Sociology http://philosophia.annales.umcs.pl Data: 26/04/2023 14:08:03

został nazwany późnowestfalskim ${ }^{41}$. Hybrydowość obecnego ładu międzynarodowego jest warunkowana, według M. Pietrasia, przez wiele zmiennych, związanych przede wszystkim z polityką, gospodarką, technologią, ekologią (w tym zmianami klimatu), psychologią i innymi ${ }^{42}$. W ramach sił politycznych kluczową rolę w tworzeniu współczesnego ładu międzynarodowego stanowi myśl liberalna, odnosząca się także do gospodarki ${ }^{43}$. Dominującym systemem gospodarczym na świecie jest kapitalizm, który - zgodnie z liberalną myślą gospodarczą - jest oparty na prywatnych środkach produkcji, a celem ich właścicieli jest pomnażanie zysków przez rozwój związany z ekspansją gospodarczą. Tak rozumiany rozwój przeliczany jest również na wzrost produktu krajowego poszczególnych państw, któremu służy głównie wzrost liczby ludności, zagospodarowywanie nowych terenów i zasobów, wykorzystywanie większych ilości energii, specjalizacja, nowe technologie ${ }^{44}$. Pierwsze trzy czynniki jednoznacznie negatywnie oddziałują na możliwość łagodzenia zmian klimatu. Kolejne dwa mogą mieć zarówno pozytywny, jak i negatywny wpływ na realizację tego zamierzenia. Dominacja liberalnego, a właściwie neoliberalnego, ładu gospodarczego traktowana jest ponadto jako bariera rozwojowa wielu regionów świata, umożliwiająca jednocześnie zachowanie najważniejszej pozycji gospodarczej państwom wysoko rozwiniętym i korporacjom, które się z nich wywodząa . Problem jest szczególnie istotny, biorąc pod uwagę fakt, że najmniej zamożne państwa świata są zarazem najbardziej narażone na skutki zmian klimatu, za które w głównej mierze odpowiedzialne są państwa najbogatsze, których gospodarki rozwinęły się m.in. za sprawą wykorzystywania znacznych ilości paliw kopalnych. Współczesny ład międzynarodowy, ze względu na nierówności gospodarcze i nierówności szans rozwojowych, można zatem uznać za niesprawiedliwy. Zgodnie z myślą alterglobalistyczną jest on gospodarczą wersją historycznego już kolonializmu. Globaliści natomiast uznają obecny kształt globalizacji, w tym gospodarczej, za szansę dla pomyślnego rozwoju społecznego i gospodarczego świata. Te dwie skrajnie różne oceny współczesnego ładu międzynarodowego dotyczą jednak tego samego systemu gospodarczego (kapitalizmu), opartego na wyżej opisanych zasadach.

Perspektywa nasilającego się wzrostu średniej temperatury na Ziemi i innych, związanych z tym zjawiskiem, zmian klimatycznych dostarcza wizji wielu negatywnych skutków dla rozwoju społecznego i zachowania obecnego porządku międzynarodowego. W przypadku dalszego nadmiernego wykorzystywania paliw

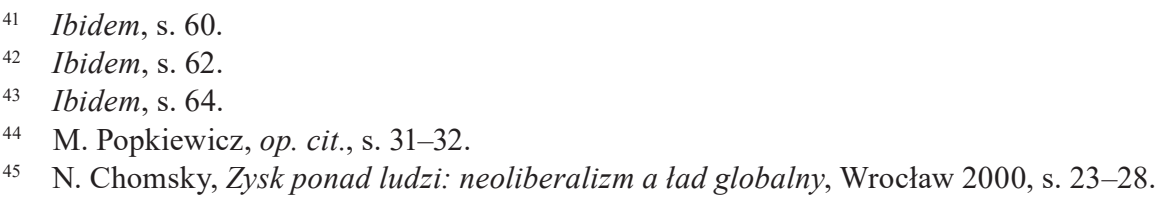


Pobrane z czasopisma Annales I - Philosophy and Sociology http://philosophia.annales.umcs.pl Data: 26/04/2023 14:08:03

Zmiany klimatu jako czynnik warunkujący transformację przyszłych stosunków...

225

kopalnych i przekształcania powierzchni Ziemi stężenie ekwiwalentu dwutlenku węgla w atmosferze na koniec XXI w. może przekroczyć 700 ppm, co związane jest z perspektywą wzrostu temperatury na Ziemi o $3-4^{\circ} \mathrm{C}$ w stosunku do lat 1861-188046. Tak znaczna zmiana będzie się wiązała $\mathrm{z}$ nasileniem negatywnych skutków społecznych i gospodarczych. Niepodjęcie działań mających na celu obniżenie emisji gazów cieplarnianych i ich stężenia w atmosferze doprowadzi do wyraźnego podniesienia poziomu mórz i oceanów, których woda zaleje wiele przybrzeżnych terenów, prowadząc do migracji ludności zamieszkującej te obszary na inne terytoria. Przedłużające się susze doprowadzą do wzrostu poziomu stresu wodnego - przeważnie na obszarach, na których ludność już zmaga się z tym zjawiskiem i doświadcza jego dramatycznych skutków. W wielu innych częściach świata problemem będą natomiast prawdopodobnie większe opady deszczu w krótkim czasie, co stanie się przyczyną częstszych i bardziej uciążliwych dla ludzi powodzi. Niezwykle istotnym zagrożeniem będzie również nasilone roztapianie się lądolodów i lodowców górskich. Ubytek tych drugich, będących źródłem wody pitnej dla wielu ludzi na świecie, będzie prowadził najpierw do powodzi, a następnie do niedoboru czystej wody. Wszystkie te zmiany doprowadzą przypuszczalnie do niepokojów społecznych i politycznych nie tylko w granicach poszczególnych państw, ale też poza nimi. Wzrost ilości regionów niestabilnych politycznie i gospodarczo z dużym prawdopodobieństwem spowoduje załamanie systemu gospodarczego opartego na ekspansjonizmie i wzroście. Dodatkowym utrudnieniem staną się koszty związane ze szkodami powstałymi na skutek zmian klimatu, które szacuje się na poziomie między 5 a 20\% $\mathrm{PKB}^{47}$. Mając na uwadze, że najdotkliwsze skutki zmian klimatu będą odczuwane w krajach najuboższych, wśród ich społeczeństw prawdopodobnie nasili się także poczucie niesprawiedliwości. W tak zmienionej i niestabilnej sytuacji międzynarodowej utrzymanie globalnego porządku społeczno-gospodarczego z pierwszych dekad XXI w. na końcu tego stulecia będzie mało prawdopodobne. Ponadto współczesny ład gospodarczy, mający niezwykle duże znaczenie dla stosunków międzynarodowych, przypuszczalnie doprowadzi do tak istotnych przeobrażeń w środowisku naturalnym, a następnie społecznym, że jego dalsze funkcjonowanie nie będzie możliwe.

Sposobem na niedopuszczenie do opisanych powyżej możliwych zmian w środowisku międzynarodowym jest podjęcie działań mających na celu zredukowanie potencjalnych negatywnych skutków zmian klimatu poprzez zmniejszenie ich nasilenia. W tym przypadku decydenci z poszczególnych państw mogą wybrać dwie drogi. Pierwsza dotyczy podjęcia działań przez wszystkie kraje świata w podobnej

46 R.K. Pachauri, L. Meyer (Hrsg.), op. cit., s. 9.

47 N. Stern, op. cit., s. 116. 
Pobrane z czasopisma Annales I - Philosophy and Sociology http://philosophia.annales.umcs.pl Data: 26/04/2023 14:08:03

skali, bez zważania na historyczną odpowiedzialność państw wysoko rozwiniętych za nasilenie problemu. Druga także jest związana z działaniami wszystkich państw świata, jednakże z uwzględnieniem ich możliwości gospodarczych i odpowiedzialności za wyemitowane w przeszłości gazy cieplarniane. Istnieje jeszcze jedna perspektywa - podjęcie aktywności tylko przez państwa wysoko rozwinięte. Nie przyczyni się ona jednak, zważając na obecne trendy rozwojowe dotyczące wzrostu emisyjności gospodarek państw rozwijających się, do rozwiązania problemu, a jedynie nieznacznie zmniejszy jego skutki.

Zważając na rozbieżność stanowisk dotyczących globalnego porozumienia w sprawie przeciwdziałania zmianom klimatu, motywowanych głównie czynnikami ekonomicznymi, należy stwierdzić, że równoczesne podjęcie działań mających na celu redukcję gazów cieplarnianych przez wszystkie albo większość państw świata jest niezwykle trudnym zadaniem, co wiąże się przede wszystkim z naruszeniem zasady sprawiedliwości międzynarodowej, związanej z odpowiedzialnością historyczną państw wysoko rozwiniętych. Państwa te nierzadko emitują kilkakrotnie więcej gazów cieplarnianych na mieszkańca niż kraje rozwijające się ${ }^{48}$. Gdyby przyjąć, że wszystkie państwa świata miałyby zredukować emisję gazów cieplarnianych o $90 \%$ w stosunku do określonego wcześniej roku bazowego, stosunek tych nierówności pozostałby taki sam, jak przed podjęciem takiego wyzwania. Mając na uwadze powyższe, trudno byłoby oczekiwać, aby wszystkie państwa świata w podobnym czasie i skali podjęły działania ograniczające ich wpływ na nasilenie efektu cieplarnianego. Mogłoby to być odbierane przez społeczeństwa krajów rozwijających się jako próba ich dalszej marginalizacji gospodarczej poprzez niemożność osiągnięcia wyższego poziomu wzrostu gospodarczego takimi samymi środkami, jak w przypadku państw, które w ten sposób znacznie się wzbogaciły. Należy mieć jednocześnie na uwadze, że technologie umożliwiające ograniczenie emisji gazów cieplarnianych (np. elektrownie wiatrowe o wysokiej mocy), dostępne dla krajów z rozwiniętymi gospodarkami, często nie są w zasięgu ubogich państw zarówno przez brak dostępu do tych technologii, jak i - co jest tego pochodną - przez ich wysokie ceny. Wydaje się zatem bardzo prawdopodobne, że w przypadku przyjęcia opisanego wyżej kierunku przeciwdziałania zmianom klimatu antagonizmy międzynarodowe na linii państw bogatych i ubogich by się pogłębiły. Ponadto dalsza marginalizacja krajów rozwijających się nasiliłaby istniejące w ich granicach problemy, co prowadziłoby do częstszych konfliktów i w ich obrębie, i poza ich granicami, nie pozostając bez skutków dla państw bogatych.

48 CO2 emissions (metric tons per capita), https://data.worldbank.org/indicator/EN.ATM. CO2E.PC?view=chart [dostęp: 03.04.2018]. 
Pobrane z czasopisma Annales I - Philosophy and Sociology http://philosophia.annales.umcs.pl Data: 26/04/2023 14:08:03

Zmiany klimatu jako czynnik warunkujący transformację przyszłych stosunków...

227

Innym kierunkiem działania jest ustalenie wartości emisji gazów cieplarnianych na mieszkańca. Przyjęcie tej wielkości, w stosunku do dwutlenku węgla, na poziomie 0,5 t rocznie oznaczałoby redukcję emisji tego gazu w skali globalnej na poziomie $90 \%$. W poszczególnych państwach wartości względne jednakże znacznie by się różniły. W krajach emitujących $1 \mathrm{t} \mathrm{CO}_{2}$ na osobę redukcja wynosiłaby $50 \%$, w tych natomiast, w których wydzielanie do atmosfery tego gazu jest na znacznie wyższym poziomie (np. 15 t per capita), ograniczenie to osiągnęłoby prawie $97 \%$. Rozwiązanie to, robiące wrażenie znacznie bardziej sprawiedliwego, wiązałoby się jednak z niektórymi wymienionymi wyżej problemami, gdyż nadal ograniczałoby drogę rozwoju gospodarczego państwom najbiedniejszym, którą państwa najbogatsze pokonały w oparciu o paliwa kopalne.

Ostatnim możliwym kierunkiem zmiany jest podjęcie działań mających na celu ograniczenie antropogenicznego oddziaływania na system klimatyczny przez wszystkie lub większość państw świata, z jednoczesnym dążeniem do współpracy międzynarodowej w tej kwestii, opartej na sprawiedliwości. To właśnie sprawiedliwość międzynarodowa jest jednym z najważniejszych elementów skuteczności działań na rzecz ochrony klimatu ${ }^{49}$. W ten sposób poważnie do ograniczenia emisji gazów cieplarnianych może podejść większość państw świata ${ }^{50}$. Istotną składową tej sprawiedliwości jest pomoc finansowa i technologiczna państw wysoko rozwiniętych dla tych rozwijających się. Poprzez takie działanie kraje pomagające będą mogły wspomóc niskoemisyjny rozwój państw rozwijających się, bez uszczerbku dla tempa rozwoju tych drugich. Dzięki takiemu działaniu kraje rozwijające się będą dużo bardziej skłonne poprzeć działania międzynarodowe mające na celu ograniczenie emisji gazów cieplarnianych. W przypadku takiego rozwiązania kraje najuboższe nie tylko znajdą się w koalicji dla rozwiązania wspólnego problemu z krajami zamożnymi, ale też będą miały szansę na rozwój w oparciu o zasoby odnawialne, co przyczyni się do poprawy stanu środowiska naturalnego zarówno w skali globalnej, jak i regionalnej. Ponadto globalna współpraca w tym kształcie umożliwi skuteczniejszą walkę z ubóstwem w państwach najmniej rozwiniętych gospodarczo. Niewątpliwie takie rozwiązanie nie jest wolne od problemów. Ten kierunek zmiany wiązałby się z odejściem od charakterystycznego dla westfalskiego ładu międzynarodowego kształtowania interesów społecznych w granicach suwerenności państwowej oraz od międzynarodowej ekspansji gospodarczej, typowej dla liberalnej myśli globalizującego się świata, na rzecz innej jakości globalizacji - współpracy międzynarodowej opartej na zasadach sprawiedliwości społecznej, za sprawą której w najwyższym stopniu można zminimalizować

49 N. Stern, op. cit., s. 122.

50 Ibidem. 
Pobrane z czasopisma Annales I - Philosophy and Sociology http://philosophia.annales.umcs.pl Data: 26/04/2023 14:08:03

228

Marcel Błoch

konflikty lokalne, regionalne i globalne. Taka zmiana może zostać przeprowadzona w przypadku wzrostu świadomości społecznej dotyczącej zagrożeń ekologicznych (w tym klimatycznych) dla pomyślnego rozwoju społecznego całego świata oraz dzięki przyjęciu wspólnych celów w tym zakresie przez wszystkie albo zdecydowaną większość państw świata.

\section{UWAGI KOŃCOWE}

Zmiany klimatu, które stanowią ciąg zdarzeń, poczynając od działalności gospodarczej ludzkości, przez zmiany w składzie powietrza atmosferycznego, po wzrost średniej temperatury na Ziemi, prowadzą do znacznych przeobrażeń w środowisku naturalnym i społecznym. Ludzkość jest zarazem przyczyną problemu i odbiorcą jego konsekwencji. Zmiany klimatu, będąc skutkiem działań jednostkowych i wynikiem systemów gospodarczych poszczególnych państw, nastawionych na zysk finansowy i nieprzerwaną ekspansję gospodarczą, także oddziałują na ten porządek. Współczesne stosunki międzynarodowe oparte są na zasadzie suwerenności państw. Jednocześnie dominujący kapitalistyczny system gospodarczy ugruntowuje powstałe w wyniku procesów historycznych nierówności pomiędzy państwami i regionami. Za współczesne zmiany klimatu największą odpowiedzialność ponoszą państwa najbogatsze, które rozwinęły się głównie przez wykorzystywanie na dużą skalę paliw kopalnych, odpowiedzialnych w największym stopniu za wzrost stężenia gazów cieplarnianych w atmosferze. Skutki zmian klimatu najdotkliwiej odczuwane są i będą jednak szczególnie przez państwa, których odpowiedzialność za skalę problemu jest najmniejsza.

W przypadku niepodjęcia działań mających na celu redukcję antropogenicznej presji na klimat, podziały pomiędzy państwami biednymi i bogatymi się pogłębią. Już obecnie można zaobserwować wiele negatywnych skutków zmian klimatu wśród społeczności najbardziej na nie narażonych. Przedłużające się okresy suszy, intensywniejsze deszcze i powodzie, szybsze topnienie lodowców górskich oraz podnoszenie się poziomu mórz i oceanów to tylko kilka z wielu zmian prowadzących do dramatycznych skutków dla ludzi, w tym do utraty miejsca zamieszkania, a nawet życia. Jeśli będzie dochodzić do dalszego wzrostu stężenia w atmosferze gazów cieplarnianych, do końca XXI w. problemy te znacznie się nasilą, prowadząc przypuszczalnie do dużo większych strat dla ludzkości. Szczególne nasilenie tych zmian w niektórych regionach doprowadzi do jeszcze większego ubóstwa, niemożności wyżywienia, a nierzadko również do braku dostępu do czystej wody, czego wynikiem będzie z kolei wzrost niepokojów społecznych, konflikty i migracje. Skutki te nie pozostaną bez wpływu też na inne części świata, co doskonale obrazuje wojna domowa w Syrii. Tak znaczny wzrost niestabilności społecznej i utrata 
Pobrane z czasopisma Annales I - Philosophy and Sociology http://philosophia.annales.umcs.pl Data: 26/04/2023 14:08:03

Zmiany klimatu jako czynnik warunkujący transformację przyszłych stosunków...

229

wielu obszarów (np. poprzez ich zalanie przez wzrastający poziom mórz i oceanów) najprawdopodobniej doprowadzą do znaczących przeobrażeń współczesnego ładu międzynarodowego, w którym dalsza ekspansja gospodarcza zostanie w dużym stopniu ograniczona, a nasilające się problemy społeczne doprowadzą do jeszcze wyraźniejszych antagonizmów zarówno wewnątrz państw, jak i pomiędzy nimi.

Jedynym możliwym kierunkiem zmian, chroniącym przed opisanymi powyżej przeobrażeniami w stosunkach międzynarodowych, wydaje się być podjęcie globalnych działań mających na celu ograniczenie stężenia gazów cieplarnianych w atmosferze. W ramach tego rozwiązania istnieje wiele możliwych scenariuszy. Aby zapobiec znacznym zmianom w środowisku naturalnym, mającym wpływ na życie ludzi, działania musiałyby podjąć władze wszystkich państw świata albo znacznej ich większości. Podjęcie takiej aktywności przez wszystkie państwa, bez zważania na poziom ich rozwoju społeczno-gospodarczego oraz możliwości finansowe, mogłoby jednak doprowadzić do nasilenia podziałów pomiędzy państwami biednymi i bogatymi, utrudniając jednocześnie tym pierwszym wyjście z ubóstwa, co miałoby długotrwałe skutki dla stabilności tych podmiotów i całego systemu międzynarodowego. Innym rozwiązaniem jest podjęcie wysiłków zmierzających do zminimalizowania antropogenicznej presji na klimat przez wszystkie państwa świata, ale $z$ uwzględnieniem ich potencjału finansowego i technologicznego. Ten kierunek zmiany wiązałby się z nadrzędnym znaczeniem sprawiedliwości w stosunkach międzynarodowych. Państwa ubogie otrzymałyby pomoc finansową i technologiczną od krajów wysoko rozwiniętych gospodarczo, co pozwoliłoby na wprowadzenie w ich granicach rozwoju opartego o zasoby odnawialne i niskoemisyjne. Państwa bogate zaś zrekompensowałyby w ten sposób swoją historyczną odpowiedzialność za powstanie problemu.

Kierunek przyszłych zmian ładu międzynarodowego jest obecnie nieznany. Uzależniony jest on przede wszystkim od woli władz i obywateli wszystkich państw, którzy mogą podjąć współpracę na rzecz zapobiegania wpływowi człowieka na system klimatyczny lub zaniechać takiego działania. Niezależnie od wybranego kierunku jedno wydaje się być nieuniknione - problem zmian klimatu doprowadzi do istotnych przeobrażeń w stosunkach międzynarodowych i funkcjonowaniu współczesnego ładu międzynarodowego.

\section{BIBLIOGR AFIA}

2,1 mld ludzi na świecie nie ma dostępu do wody pitnej w miejscu zamieszkania, a ponad dwa razy więcej pozbawionych jest odpowiednich warunków sanitarnych, www.unicef.pl/Centrum-prasowe/Informacje-prasowe/2-1-mld-osob-na-swiecie-nie-ma-dostepu-do-wody-pitnej-wmiejscu-zamieszkania-a-ponad-dwa-razy-wiecej-pozbawionych-jest-odpowiednich-warunkow-sanitarnych [dostęp: 30.05.2018]. 
20 faktów o zakwaszeniu oceanów, http://naukaoklimacie.pl/aktualnosci/20-faktow-o-zakwaszaniu-oceanow-42 [dostęp: 30.05.2018].

Bangladesz. Przed nami sztorm, www.national-geographic.pl/national-geographic/ludzie/bangladesz-przed-nami-sztorm [dostęp: 03.04.2018].

Chomsky N., Zysk ponad ludzi: neoliberalizm a ład globalny, Wrocław 2000.

Ciszak P., Arktyka nowym El Dorado Putina. Rosja szykuje się do wojny o surowce ukryte pod lodem, www.money.pl/gospodarka/wiadomosci/artykul/arktyka-ropa-gaz-rosja-usa,23,0,2320151. html [dostęp: 03.04.2018].

CO2 emissions (metric tons per capita), https://data.worldbank.org/indicator/EN.ATM.CO2E. PC?view=chart [dostęp: 03.04.2018].

Cowie J., Zmiany klimatyczne. Przyczyny, przebieg i skutki dla człowieka, Warszawa 2009.

https://data.worldbank.org/indicator/SP.POP.TOTL?locations=BD\&name_desc=false\&view=chart [dostęp: 03.04.2018].

Karaczun Z., Zmiany klimatu a bezpieczeństwo narodowe Polski, Warszawa 2011.

Kelley C.P., Mohtadib S., Canec M.A., Seagerc R., Kushnirc Y., Climate change in the Fertile Crescent and implications of the recent Syrian drought, www.pnas.org/content/112/11/3241. full.pdf [dostęp: 03.04.2018].

Kozielecki M., Co to jest zakwaszenie oceanów?, www.zielonazmiana.pl/edukacja/ekologia/zakwaszenie-oceanow [dostęp: 03.04.2018].

Kundzewicz Z., Cieplejszy świat. Rzecz o zmianach klimatu, Warszawa 2013.

Pachauri R.K., Meyer L. (Hrsg.), Klimaänderung 2014. Synthesebericht, 2015, www.ipcc.ch/pdf/ reports-nonUN-translations/deutch/IPCC-AR5_SYR_barrierefrei.pdf [dostęp: 03.04.2018].

Pietraś M., Hybrydowość późnowestfalskiego ładu międzynarodowego, [w:] M. Pietraś, K. Marzęda-Młynarska (red.), Późnowestfalski ład międzynarodowy, Lublin 2008.

Pietraś M., Międzynarodowy reżim zmian klimatu, Torun 2011.

Popkiewicz M., Świat na rozdrożu, Katowice 2012.

Population, total, https://data.worldbank.org/indicator/SP.POP.TOTL?name_desc=false\&view=chart [dostęp: 03.04.2018].

Powódź, monsun, osuwiska. Sity natury pustosza Azję, https://tvnmeteo.tvn24.pl/informacje-pogoda/swiat,27/powodz-monsun-osuwiska-sily-natury-pustosza-azje,236465,1,0.html [dostęp: 03.04.2018].

Progress on Drinking Water, Sanitation and Hygiene, www.unicef.org/publications/files/Progress on_Drinking_Water_Sanitation_and_Hygiene_2017.pdf [dostęp: 03.04.2018].

Rosna emisje gazów cieplarnianych z rolnictwa, http://dlaklimatu.pl/rosna-emisje-gazow-cieplarnianych-z-rolnictwam [dostęp: 30.05.2018].

Skawiński P., Monsun przynosi teraz tylko nieszczęście, http://wiadomosci.dziennik.pl/swiat/ artykuly/533833,indie-monsun-powodz-nieszczescie-reportaz-zdjecia.html [dostęp: 03.04.2018].

Stern N., Globalny ład. Zmiany klimatu a powstanie nowej epoki postępu i dostatku, Warszawa 2010.

Śmigrowska M., Popkiewicz M., Golfsztrom najsłabszy od ponad 1000 lat, http://ziemianarozdrozu. pl/artykul/3009/golfsztrom-najslabszy-od-ponad-1000-lat [dostęp: 03.04.2018].

Tragiczne skutki monsunu. 1200 ofiar śmiertelnych, miliony osób bez dachu nad głowa, https:// tvnmeteo.tvn24.pl/informacje-pogoda/swiat,27/tragiczne-skutki-monsunu-1200-ofiarsmiertelnych-miliony-osob-bez-dachu-nad-glowa,239439,1,0.html [dostęp: 03.04.2018].

Trends in Atmospheric Carbon Dioxide, Earth System Research Laboratory, www.esrl.noaa.gov/ $\mathrm{gmd} / \mathrm{ccgg} /$ trends/graph.html [dostęp: 03.04.2018].

Zmiana klimatu 2013. Fizyczne podstawy naukowe. Podsumowanie dla Decydentów, Warszawa 2015, www.ipcc.ch/pdf/reports-nonUN-translations/polish/ar5-wg1-spm.pdf [dostęp: 30.04.2018]. 


\section{SUMMARY}

This article is about climate change as a factor which affects social life and is going to have an important meaning in the transformation of modern international relations in the future, for this purpose, the simplified scheme of changes has been described, on the one hand, people and their economic activities are the source of the problem and, on the other, the recipients of its effects. It further describes the foundations of modern international order, with an indication of its links with the economic governance. On this basis, the author told about possible developments in the international environment consider both passivity and international action about the problem.

Keywords: climate change; international order; international relations

\section{STRESZCZENIE}

Niniejszy artykuł traktuje o zmianach klimatu jako czynniku, który oddziałując na życie społeczne, będzie miał istotne znaczenie dla przeobrażenia współczesnych stosunków międzynarodowych w przyszłości. W opracowaniu został opisany uproszczony schemat zmian klimatu, wskazujący, że z jednej strony ludzie i ich działalność gospodarcza są źródłem problemu, z drugiej natomiast są odbiorcami jego skutków. W dalszej kolejności opisano podstawy współczesnego ładu międzynarodowego ze wskazaniem na jego powiązania z ładem gospodarczym. Na tej podstawie omówiono możliwe kierunki zmian w środowisku międzynarodowym, uwzględniając zarówno bierność w sprawie przeciwdziałania problemowi, jak i podjęcie międzynarodowych działań w tym zakresie.

Słowa kluczowe: zmiany klimatu; ład międzynarodowy; stosunki międzynarodowe 